\title{
PENDAPAT ULAMA MUI KOTA MALANG TERHADAP JUAL BELI ACCOUNT CLASH OF CLANS (COC)
}

\author{
Iin Yuliastutik \\ Fakultas Syariah UIN Maulana Malik Ibrahim Malang \\ Email: iinazzahida117@gmail.com
}

\section{Abstract}

Looking at the phenomenon purchase transactions are growing today, a lot going on sale and purchase of Clash of Clans Account (COC) through online, as happened in the Facebook group "Sell Buy Clash OfClans Indonesia". In the case of sale and purchase of Clash of Clans Account (COC) of the goods bought and sold does not belong to gamers, but belongs to the game master. As in the object of sale and purchase of goods bought and sold the goods can be used, the goods are in the hands diakadkan and reserved people who do contract. But the issue this time the goods are bought and sold is not privately owned but belongs to the game master. But in reality rife Clash of Clans Account bought and sold, where buying and selling did not meet the elements that exist in buying and selling, but selling is still rife among gamers.

Melihat fenomena transaksi jual beli yang berkembang saat ini, banyak terjadi jual beli Account Clash of Clans (COC) melalui online, seperti yang terjadi di grup Facebook "Jual Beli Clash Of Clans Indonesia". Pada kasus jual beli Account Clash of Clans (COC) tersebut barang yang diperjualbelikan bukan milik pemain game, melainkan milik game master. Sebagaimana dalam objek jual beli barang yang diperjualbelikan yakni barang dapat dimanfaatkan, barangyang diakadkan ada ditangan dan milik orang yang melakukan akad. Namun dalam permasalahan kali ini barang yang diperjualbelikan bukan milik pribadi melainkan milik game master. Akan tetapi dalam kenyataannya Account Clash of Clans marak diperjualbelikan, yang mana jual beli ini tidak memenubi unsur-unsur yang ada dalam jual beli, akan tetapi jual beli tersebut masih marak di kalangan gamer.

Keywords: Opinions Ulama MUI, Purchase, Clash of Clans (COC) 


\section{Pendahuluan}

Jual beli online yang marak dan banyak diminati oleh para konsumen, dikarena para konsumen malas untuk keluar rumah dan akses internet saat ini mulai canggih, lewat handphone (HP) seseorang bisa melakukannya. Misalnya jual beli online yang terdapat di akun social Facebook, Twitter, Blogger, OLX dan lain-lain. Pembeli dapat melihat barang-barang yang diperjual belikan, ID atau Account Clash of Clans (COC) juga diperjual belikan secara online. Pada transaksi jual beli secara elektronik dan dunia maya sama halnya dengan transaksi jual beli yang dilakukan dalam dunia nyata, dilakukan oleh pihak terkait, walaupun jual beli secara elektronik ini pihak-pihaknya tidak bertemu secara langsung satu sama lain, tetapi berhubungan melalui internet.

Clash of Clans adalah salah satu game online yang diperjualbelikan. Clash of Clans juga dapat diartikan dengan suatu jenis permain yang membangun komunitas, melatih pasukan, dan menyerang pemain lain untuk mendapatkan emas dan Elixir, yang mana emas dan Elixir dapat digunakan untuk membangun pertahanan yang melindungi pemain dari serangan pemain lain, untuk melatih dan meng-upgrade pasukan. permainan ini juga dilengkapi kampanye pseudo-satu pemain di mana pemain harus menyerang serangkaian benteng desa goblin. ${ }^{1}$ Clash of Clans (COC) merupakan sebuah game atau permainan di handphone (HP) game strategi yang bercerita tentang pertarungan antar clan di masa lalu. Dalam game ini, pemain akan berperan sebagai pemimpin dimana pemimpin harus membangun desa dan membuat pasukan untuk melindungi desa atau menyerang desa lain. ${ }^{2}$ Cara bermain Clash of Clans (COC) pemain harus mendownload aplikasi di my store (tempat download aplikasi di android atau IOS).

Permasalahan jual beli Account Clash of Clans (COC) ini adalah mengenai kejelasan barang (bentuk/kepemilikan) mutlak dibutuhkan. Pada kasus ini barang yang diperjualbelikan dalam game online adalah tidak jelas baik dari bentuknya yang tidak nyata maupun kepemilikannya yang sebenarnya bukan milik pemain game, melainkan milik game master (GM). ${ }^{3}$ Pada dasarnya jual beli Account Clash of Clans (COC) ini bersifat sebagai hiburan yang tidak bermanfaat.

Melihat fenomena transaksi jual beli yang berkembang saat ini, banyak terjadi jual beli Account Clash OfClans (COC) melalui online, seperti yang terjadi di grup Facebook "Jual Beli Clash Of Clans Indonesia”. Alasan penulis yang juga melakukan penelitian di ulama MUI kota malang, karena pada kasus jual beli

1 http://id.wikipedia.org/wiki/Clash_of_Clans di akses tanggal 07-03-2016

2 https://jalantikus.com di akses tanggal 07-03-2016

3 http://www.fadli.xyz/2015/05/hukum-jual-beli-barang-game-online.html diakses pada 19 mei 2016 
Account Clash Of Clans (COC) tersebut barang yang diperjualbelikan bukan milik pemain game, melainkan milik game master. Sebagaimana dalam objek jual beli barangyang diperjualbelikan yakni barang dapat dimanfaatkan, barang yang diakadkan ada ditangan dan milik orang yang melakukan akad. Namun dalam fenomenanya tidak seperti yang terdapat dalam objek jual beli. Sedangkan dalam hadits yang diriwayatkan Abu Daud:

\section{Artinya: "jangan engkau jual barang yang tidak engkau miliki

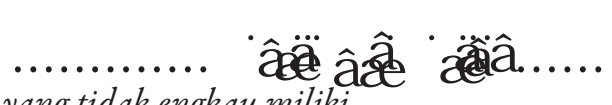

Hadits diatas menjelaskan apabila suatu akad jual beli terjadi, maka barang yang diperjualbelikan milik sendiri, namun dalam permasalahan kali ini barang yang diperjualbelikan bukan milik pribadi melainkan milik game master. Namun dalam kenyataannya account clash of clans marak diperjualbelikan yang mana jual beli ini tidak memenuhi unsur-unsur yang ada dalam jual beli, akan tetapi jual beli tersebut masih marak di kalangan gamer.

Berdasarkan permasalahan di atas, maka fokus pembahasan adalah: (1) Praktek transaksi jual beli Account Clash OfClans (COC) di akun sosial facebook “jual beli Clash Of Clans Indonesia”. (2) Pendapat Ulama’ MUI Kota Malang tentang praktek transaksi jual beli Account Clash Of Clans (COC).

\section{Konsep tentang Jual Beli}

Jual beli atau perdagangan dalam istilah fiqih disebut dengan al-bai' yang menurut etimologi berarti menjual atau mengganti. Wahbah Al-Zuhaily mengartikannya secara bahasa dengan "menukar sesuatu dengan sesuatu yang lain”. Kata al-bai' dalam Arab terkadang digunakan untuk pengertian lawannya, yaitu kata al-syira' (beli). Dengan demikian kata al-bai'berarti jual, tetapi sekaligus juga berarti beli. ${ }^{4}$

Secara terminologi terdapat beberapa definisi jual beli yang dikemukakan para ulama' fiqh sekalipun substansi dan tujuan masing-masing definisi sama. Sayyid sabiq mendefinisikan jual beli dengan " jual beli adalah pertukaran harta deng harta atas dasar saling merelakan atau memindahkan milik dengna ganti yang didapat dibenarkan.

Definisi lain dikemukakan oleh ulama' Hanafiyah yang yang dikutip oleh Wahbah al-Zuhaily, jual beli adalah saling tukar harta dengan harta melalui cara tertentu. Atau tukar-menukar sesuatu yang diinginkan dengan yang sepadan

4 Abdul Rahman Ghazali, dkk, Fiqh Muamalah, (Jakarta: Prenada Media Group, 2010), h. 6768 
melalui cara tertentu yang bermanfaat.

Definisi lain yang dikemukakan Ibn Qudamah (salah seorang ulama Malikiyah) yang dikutip oleh Wahbah al-Zuhaily, jual beli adalah saling menukar harta dengan harta dalam bentuk pemindahan milik dan kepemilikan.

Sedangkan menurut ulama' Hanafiyah pengertian jual beli (al-bai') secara definitif adalah tukar-menukar harta benda atau sesuatu yang diinginkan dengan sesuatu yang sepadan melalui cara tertentu yang bermanfaat. Adapun menurut ulama' Malikiyah, Syafi'iyah, dan Hanabilah, bahwa jual beli (al-bai) tukar-menukar harta dengan harta pula dalam bentuk pemindahan milik dan kepemilikan. ${ }^{5}$

Dalam Kompilasi Hukum Ekonomi Syariah bab IV Pasal 57 bahwasanya pihak-pihak yang terkait dalam perjanjian jual beli tei atas penjual, pembeli dan pihak lain yang yang terlibat dalam perjanjian jual beli tersebut. ${ }^{6}$

Dari beberapa definisi di atas dapat dipahami bahwa inti dari pengertian jual beli adalah suatu perjanjian tukar-menukar benda atau barang yang mempunyai nilai secara sukarela antara kedua belah pihak, yang satu menerima benda-benda dan pihak lain menerimanya sesuai dengan perjanjian atau ketentuan yang dibenarkan syara' dan disepakati. Sesuai dengan ketetapan hukum syara' maksudnya adalah memenuhi persyaratan-persyaratan,rukun-rukun dan hal-hal lain yang berkaitan dengan jual beli sehingga bila syarat-syarat dan rukunnya tidak terpenuhi berarti tidak sesuai dengan kehendak syara'.

Rukun dan syarat sahnya jua lbeli Menurut mazhab Hanafi yang dikutip oleh M. Ali Hasan, rukun jual beli hanya ijab dan qabul saja. Yang menjadi rukun dalam jual beli itu hanyalah kerelaan antara kedua belah pihak untuk berjual beli. Namun, karena unsur kerelaan berhubungan dengan hati sering tidak kelihatan, maka perlu indikator (qarinab) yang menunjukkan kerelaan tersebut dari kedua belah pihak. Indikator tersebut bisa dalam bentuk perkataan (ijab dan qabul) atau dalam bentuk perbuatan, yakni saling memberi (penyerahan barang, dan penerimaan uang). Dalam fiqh, hal ini terkena dengan istilah "bai al-muathah".

Menurut Jumhur ulama, rukun jual beli itu ada empat, yaitu sebagai berikut:

1. Orang yang berakad (penjualdan pembeli)

2. Sighat (lafadz Ijab dan qabul)

3. Ada barang yang dibeli

4. Ada nilai tukar pengganti barang

5 Abdurrahman Al-Jaziri, Fiqh Empat Madzhab 6, (Jakarta: Darul Ulum Press, 2001), h. 14.

6 Kompilasi Hukum Ekonomi Syariah, Buku II Pasal 20 ayat 19

7 M. Ali Hasan, Berbagai Macam Transaksi Dalam Islam (Jakarta: Raja Grafindo Persada, 2004), h. 118 
Sedangkan syarat sahnya jual beli terdiri dari syarat subjek, syarat objek dan lafadz. Penjelasan mengenainya adalah sebagai berikut:

a) Syarat yang menyangut subjek jual beli

Bahwa penjual dan pembeli selaku subjek hukum dari perjanjian jual beli harus memenuhi persyaratan sebagai berikut:

1. Berakal sehat

2. Dengan kehendaknya sendiri (bukan dipaksa)

3. Keduanya tidak mubazir

4. Baligh (sudah dewasa)

Setelah syarat ini terpenuhi, maka perjanjian jual beli dapat dibuat dan harus selalu didasarkan pada kesepakat antara penjual dan pembeli. Sesuai dengan firman Allah SWT, yaitu:

"Hai orang-orang yang beriman, janganlah kamu salingmemakan harta sesamamu dengan jalan yang bathil, kecuali dengan jalan perniagaan yang berlaku dengan suka sama suka di antara kamu".

b) Syarat sahnya jual beli yang menyangkut Objek Perjanjian

Benda-benda yang dapat dijadikan sebagai objek jual beli haruslah memenuhi persyaratan sebagai berikut:?

1. Bersih barangnya

Bahwa di dalam ajaran Islam dilarang melakukan jual beli barang mengandung unsur najis ataupun barang-barang yang nyata-nyata diharamkan oleh ajaran agama. Minuman keras, daging babi, bangkai dan sebagainya. Di antara bangkai ada pengecualiannya, yakni ikan dan belalang.

2. Dapat dimanfaatkan

Barang yang diperjualbelikan harus mempunyai manfaat, sehingga pihak yang membelinya tidak merasa dirugikan. Pengertian manfaat ini, tentu saja bersifat relative. Karena pada dasarnya setiap barang mempunyai manfaat, sehingga untuk mengukur kriteria kemanfaatan ini hendaknya memakai kriteria agama. Pemanfaatan barang jangan sampai bertentangan dengan agama, peraturan perundang-undangan, kesusilaan, maupun ketertiban umum yang ada dalam kehidupan masyarakat.

3. Milik orang yang melakukan akad

Bahwa barang yang menjadi objek perjanjian jual beli harus benarbenar milik penjual secara sah adalah batal. Walau demikian pembeli

8 Q.S An-Nisa': 29. Al-Qur'an dan Terjemahnya. Departemen Agama Indonesia, h. 107

9 Abdul Ghofur, Hukum Perjanjian Islam di Indonesia, h. 41-44 
yang beriktikad baik tetap mendapatkan perlindungan hukum dan tidak boleh dirugikan oleh adanya perjanjian yang batal ini.

4. Mampu menyerahakan

Dalam artian barang harus sudah ada, diketahui wujud dan jumlahnya pada saat perjanjian jual beli tersebut diadakan, atau sudah ada sesuai dengan waktu penyerahan yang telah dijanjikan (dalam jual beli dengan system pemesanan).

5. Mengetahui

Artinya bahwa terhadap barang yang menjadi objek jual beli, harus secara jelas diketahui spesifikasinya, jumlahnya, timbangnya, dan kualitasnya. Hal ini merupakan ketentuan yang harus dipenuhi, karena kalau tidak termasuk gharar yang itu merupakan unsur yang dilarang dalam Islam.

6. Barang yang diakadkan ada ditangan

Artinya bahwa perjanjian yang menjadi objek perjanjian jual beli harus benar-benar berada di bawah kuasa pihak penjual. Sehingga apabila jual beli dilakukan terhadap barang milik penjual yang ada di bawah kekuasaan orang lain sebaiknya dihindarkan, karena hal ini bisa menimbulkan kerugian bagi pihak pembeli.

7. Syarat sahnya jual beli yang menyangkut lafazh

Sebagai sebuah perjanjian harus di lafadzkan, artinya secara lisan atau secara tertulis disampaikan kepada pihak lain. Dengan kata lain lafadz adalah ungkapan yang dilontarkan oleh orang yang melakukan akad untuk menunjukkan keinginannya yang mengesankan bahwa akad itu sudah berlangsung. Ungkapan itu harus mengandung serah terima (ijab qabul).

Adapun macam-macam jula beli yang perlu kita ketahui, antara lain yaitu:

\section{Jual beli yang sah}

Suatu jual beli dikatakan sebagai jual beli yang shahih apabila jual beli tersebut disyariatkan memenuhi rukun dan syarat yang ditentukan, bukan milik orang lain, tidak tergantung pula pada hak khiyar lagi, jual beli seperti ini dikatakan sebagai jual beli yang shahih. Misalnya, seseorang membeli sebuah kendaraan roda empat. Seluruh rukun dan syarat jual beli telah terpenuhi, kendaraan roda empat itu tidak diperiksa oleh pembeli dan tidak ada cacat, tidak ada rusak, tidak ada manipulasi harga dan harga buku (kwitansi) itupun telah diserahkan, serta tidak ada lagi hak khiyar dalam jual beli itu. Jual beli yang demikian ini hukumnya shahih yang telah 
mengikat kedua belah pihak. ${ }^{10}$

Ulama' sepakat bahwa jual beli dikategorikan sahih apabila dilakukan oleh orang yang baligh, berakal, dapat memilih, dan mampu ber-tasarruf secara bebas dan baik. Mereka yang dipandang tidak sah jual belinya adalah sebagai berikut: a. Jual beli orang gila

Ulama' fiqih sepakat jual beli orang gila tidak sah. Begitu pula sejenisnya, seperti orang mabuk dan sebagainya. ${ }^{11}$

b. Jual beli anak kecil

Ulama' fikih sepakat bahwa jual beli anak kecil (belum mumayyiz) dipandang tidak sah, kecuali dalam perkara-perkara yang ringan atau kecil. Menurut ulama' Syafi'iyah, jual beli anak mumayyiz yang belum balig tidak sah Adapun menurut ulama' Malikiyah, Hanafiyah, dan Hanabilah, jual beli anak kecil dianggap sah apabila ada izin walinya. Mereka antara lain beralasan, salah satu cara untuk melatih kedewasaan adalah dengan member keleluasaan untuk jual beli dan juga pengalaman, sesuai dengan firman Allah swt dalam Al-Qur'an surah an-Nisa' (4) ayat $6:^{12}$

"Dan ujilah anak-anak yatim itu sampai mereka cukup umur untuk menikah. Kemudian jika menurut pendapatmu mereka cerdas (pandai memelihara harta), maka serabkanlah kepada mereka hartanya".

c. Jual beli orang buta

Jual beli orang buta dikategorikan sah menurut jumhur ulama jika barang yang dibelinya diberi sifat (diterangkan sifat-sifatnya). Adapun menurut ulama' Syafi'iyah, jual beli orang buta itu tidak sah sebab ia tidah dapat membedakan barang yang jelek dan barang yang baik. ${ }^{13}$

d. Jual beli terpaksa

Menurut ulama' Hanafiyah, hukum jual beli orang terpaksa seperti jual beli fudul (jual beli tanpa seizin pemiliknya), yakni ditangguhkan (mauquf). Oleh karena itu, keabsahannya ditangguhkan sampai rela (hilangnya raksa terpaksa). Menurut ulama' Malikiyah tidak lain baginya ada khiyar. Adapun menurut ulama' Syafi'iyah dan Hanabilah jual beli tersebut tidak sah, karena tidak ada keridhaan ketika akad. ${ }^{14}$

e. Jual beli fudhul

Jual beli fudhul adalah jual beli milik orang tanpa seizin pemiliknya. Menurut

10 Nasrun Haroen, Fiqih Muamalah, ( Jakarta: Gaya Media Pratama, 2000), h.121

11 Rachmat Syafe'I, Fiqh Mualalah, (Bandung, Pusaka Setia, 2001), h.93

12 Departemen Agama RI, Al-Qur'an dan Terjemahnya, h. 78

13 M. Ali Hasan, Berbagai Macam Transaksi Dalam Islam, (Jakarta: PT Raja Grafindo Persada, 2003), h. 136

14 Sayyid Sabiq, Fiqh Sunnah jilid 12, (Bandung: al-Ma'arif, 1996), h. 71 
ulama' Hanafiyah dan Malikiyah jual beli ini ditangguhkan sampai ada izin pemilik. Adapun menurut ulama' Hanabilah dan Syafi'iyah jual beli fudhul tidak sah. ${ }^{15}$ f. Jual beli orang yang terhalang

Maksud terhalang disini adalah terhalang karena kebodohan, bangkrut, atau sakit. Jual beli orang bodoh yang suka mengharamkan hartanya, menurut pendapat Malikiyah, Hanafiyah, dan pendapat paling shahih dikalangan Hanabilah, harus ditangguhkan. Adapun menurut Syafi'iyah, jual beli tersebut tidah sah karena tidak ahli dan ucapannya tidak dapat dipegang. Begitu pula yang ditangguhkan jual beli orang yang sedang bangkrut berdasarkan ketetapan hukum, menurut ulama' Malikiyah dan Hanafiyah, sedangkan menurut ulama' Syafi'iyah dan Hanabilah, jual beli tersebut tidah sah. ${ }^{16}$

g. Jual beli malja'

Jual beli malja' adalah jual beli orang yang sedang dalam bahaya, yakni untuk menghindar dari perbuatan zalim. Jual beli tersebut fasid menurut ulama' Hanafiyah dan batal menurut ulama' Hanabilah. ${ }^{17}$

2. Jual beli yang batil

Jual beli yang batil yaitu jual beli yang apabila salah satu atau seluruh rukunnya tidak terpenuhi, atau jual beli tersebut pada dasar dan sifatnya tidak disyariatkan, seperti jual beli yang dilakukan anak-anak, orang gila, atau barang yang dijual itu barang-barang yang diharamkan syara’ seperti bangkai, darah, babi, dan khamar. 3. Jual beli yang fasid

Ulama' Hanafiyah yang membedakan jual beli yang fasid dengan jual beli bathil. Apabila kerusakan dalam jual beli itu terkait dengan barang yang dijualbelikan, maka hukumnya batal. Seperti memperjualbelikan barang-barang haram (khamar, babi, darah). Apabila kerusakan pada jual beli itu menyangkut harga barang dan boleh diperbaiki, maka jual beli itu menyangkut barang dan boleh diperbaiki, maka jual tersebut dinamakan fasid.

Akan tetapi jumhur ulama tidak membedakan jual beli yang fasid dengan jual beli yang batil. Menurut mereka jual beli itu terbagi menjadi dua, yaitu jual beli yang shahih dan jual beli yang batil. Apabila syarat dan rukun jual beli terpenuhi, maka jual beli sah. Sebaliknya, apabila salah satu rukun dan syarat jual beli itu tidak terpenuhi, maka jual beli itu batil. ${ }^{18}$

4. Transaksi jual beli yang barangnya tidak ada di tempat akad

Transaksi jual beli yang barangnya ada di tempat akad, hukumnya boleh

15 Rachmat Syafe'I, Fiqh Mualalah, h. 94

16 Rachmat Syafe'I, Fiqh Mualalah, h. 94-95

17 Rachmat Syafe'I, Fiqh Mualalah, h. 95

18 Nasrun Haroen, Fiqih Muamalah, h. 125-126 
dengan syarat barang tersebut diketahui dengan jelas klasifikasinya. Namun apabila barang tersebut tidak sesuai dengan apa yang diinformasikan, akad jual beli akan menjadi tidak sah, maka pihak yangmelakukan akad diperbolehkn untuk memilih menerima atau menolak, sesuai deng kesepakatan antara pihak penjual dan pembeli.

5. Transaksi atas barang yang sulit dan berbahaya untuk melihatnya

Diperbolehkan juga melakukan akad transaksi atas barang yang tidak ada ditempat akad, bila kriteria barang tersebut diketahui menurut kebiasaan, misalnya makanan kaleng, obat-obatan dalam tablet, tabung-tabung oksigen bensin dan minyak tanah melalui kran pompa dn lainnya yang tidak dibenarkan untuk dibuka kecuali pada saat penggunaannya, sebab sulit melihat benda tersebut dan membahayakan. ${ }^{19}$

\section{Pembahasan}

Seiring dengan teknologi informasi yang didukung pula dengan teknologi komputer yang semakin canggih, teknologi komunikasi pada saat ini menjadi sarana penunjang bagi penyebaran informasi hampir ke seluruh dunia. Jaringan komunikasi global dengan fasilitas teknologi komputer tersebut dikenal sebagai internet. Internet tidak hanya untuk berkomunikasi tapi fungsi lain bisa digunakan untuk Game secara online. Clash of Clans salah satu dari game online yang saat ini banyak digemari oleh anak-anak, remaja bahkan orang dewasa. Game ini mulai terkenal pada pertengahan tahun 2014, sedangkan awal munculnya pada tahun 2013 yang dikembangkan oleh perusahaan Supercell, yang bertempat di Firlandia. Akhir tahun 2014 game Clash of Clans ini mulai banyak diperjualbelikan. Account yang menyimpan data-data dari game ini yang diperjualbelikan berupa Email dan Password.

Proses pembelian dan penjualan jasa/pertukaran dan distribusi informasi antara dua pihak di dalam satu perusahaan dengan menggunakan internet, perdagangan secara face to face mulai digantikan dengan perdagangan online. Seperti halnya untuk membeli sesuatu yaitu mencari lokasi si penjual, memilih satu produk, menanyakan harga, membuat suatu penawaran, sepakat untuk melakukan pembayaran, mengecek identitas dan validitas mekanisme pembayaran, penyerahan barang oleh penjual dan penerima oleh pembeli.

Transaksi jual beli secara elektronik dan dunia maya sama halnya dengan transaksi jual beli yang dilakukan pihak terkait, walaupun jual beli secara elektronik pihak-pihaknya tidak bertemu secara langsung satu sama lain, tetapi berhubungan

19 Sayyid Sabiq, Fiqih Sunnah jilid 4, (Jakarta: Pena Pundi Aksara, 2006), h. 131-132 
melalui internet. Dalam hal transaksi jual beli di game online, tidak jarang juga terjadi penipuan. Penipuan biasanya dilakukan kepada gamer baru yang memiliki harta melimpah. Biasanya, para pemain baru yang sering terkena tipu. Sedangkan para pemain lama biasanya sudah paham modusnya.

Untuk mengantisipasi hal ini, Grand Master atau GM (sebutan bagi penyedia atau operator game) memberlakukan sistem banned (skorsing) kepada character yang dinilai kurang atau menipu. Karena itu dibutuhkan kerjasama antara gamer dan GM dalam mengantisipasi hal ini. GM akan melakukan banned chard (character) yang melanggar aturan tersebut.

Dalam transaksi menggunakan media internet terdapat juga beberapa potensi pelanggaran terhadap prinsip-prinsip muamalah, tidak terkecuali pada jual beli Account Clash of Clans sebagaimana telah dijelaskan dalam bab III, maka perlu adanya ketelitian pihak-pihak tertentu sebelum melakukan transaksi, agar tidak terjadi kerugian-kerugian di kemudian hari.

Sesuai dengan bab II skripsi jual beli Account Clash of Clans ini menggunakan teori jual beli. Jual beli (al-bai) secara definitif adalah tukar menukar harta benda atau sesuatu yang diinginkan dengan sesuatu yang sepadan melalui cara tertentu yang bermanfaat.

Dilihat dari rukun dan syarat jual beli, jual beli Account Clash of Clans ini seperti yang telah dijabarkan pada hukum Islam rukun dan syarat dalam jual beli Account Clash of Clans ini sebagai berikut:

1. Pihak-pihak yang berakad (penjual dan pembeli)

Pihak-pihak yang berakad adalah mereka yang bertransaksi dalam proses jual beli. Bagi penjualan dan pembeli ada syaratnya diantaranya yaitu orang yang melakukan akad jual beli baligh, dan berakal sehat. Jual beli dilakukan oleh orang yang merdeka bukan hamba sahaya. Penjual Account Clash of Clans yaitu mereka para pemain game Clah of Clans yang minimal pada TH 6 keatas, dan untuk TH 1-5 belum terlalu ada harganya karena tidak terlalu mahal. Sedangkan pembeli yaitu para gamer yang ingin memiliki account akan tetapi mereka tidak mau memulai memainkan game clash of clans dari awal karena terlalu lama prosesnya.

2. Obyek

Menurut hukum islam benda-benda yang dapat dijadikan sebagai objek jual beli haruslah memenuhi persyaratan sebagai berikut: ${ }^{20}$

a. Bersih barangnya

Bahwa di dalam ajaran Islam dilarang melakukan jual beli barang yang mengandung unsur najis ataupun barang-barang yang nyata-nyata diharamkan

20 Abdul Ghofur, Hukum Perjanjian Islam di Indonesia, h. 41-44 
oleh ajaran agama. Minuman keras, daging babi, bangkai dan sebagainya. Di antara bangkai ada pengecualiannya, yakni ikan dan belalang. Berbeda halnya dengan jual beli Account Clash of Clans yang tidak diketahui apakah barangnya itu bersih atau tidak, hal ini dikarenakan yang diperjualbelikan berupa email dan password yang tidak bisa diketahui kebersihan barangnya. Sebagaimana terdapat dalam kaidah fiqh telah disebutkan bahwa "asal sesuatu adalah mubah selama tidak terdapat dalil yang meunjukkan keharamanya." ${ }^{21}$

b. Dapat dimanfaatkan

Barang yang diperjualbelikan harus mempunyai manfaat, sehingga pihak yang membelinya tidak merasa dirugikan. Pengertian manfaat ini, tentu saja bersifat relatif. Karena pada dasarnya setiap barang mempunyai manfaat, sehingga untuk mengukur kriteria kemanfaatan ini hendaknya memakai kriteria agama. Pemanfaatan barang jangan sampai bertentangan dengan agama, peraturan perundang-undangan, kesusilaan, maupun ketertiban umum yang ada dalam kehidupan masyarakat. Dalam jual beli acount clash of clans ini objek yang diperjualbelikan tidak bermanfaat bagi masyarakat luas, tapi hanya bermanfaat bagi gamer.

c. Milik orang yang melakukan akad

Bahwa barang yang menjadi objek perjanjian jual beli harus benar-benar milik penjual secara sah dan apabila barang yang diperjualbelikan bukan milik penjual maka jual belinya batal. Walau demikian pembeli yang beriktikad baik tetap mendapatkan perlindungan hukum dan tidak boleh dirugikan oleh adanya perjanjian yang batal ini. Dalam fenomena jual beli Account Clash of Clans barang yang diperjualbelikan yaitu Account, yang mana account tersebut merupakan milik orang yang melakukan akad.]Mampu menyerahkan

Dalam artian barang harus sudah ada, diketahui wujud dan jumlahnya pada saat perjanjian jual beli tersebut diadakan, atau sudah ada sesuai dengan waktu penyerahan yang telah dijanjikan (dalam jual beli dengan sistem pemesanan). Dalam jual beli Account Clash of Clans barang yang diperjualbelikan tidak berwujud, tetapi dapat diserah terimakan.

d. Barang yang diakadkan ada di tangan

Artinya bahwa perjanjian yang menjadi objek perjanjian jual beli harus benar-benar berada di bawah kuasa pihak penjual. Sehingga apabila jual beli dilakukan terhadap barang milik penjual yang ada di bawah kekuasaan orang lain sebaiknya dihindarkan, karena hal ini bisa menimbulkan kerugian bagi pihak pembeli. Berbeda halnya dengan jual beli account Clash of Clans barang yang diperjualbelikan merupakan milik penjual account tersebut.

21 Imam Musbikin,2001, qawa'id al-fiqhiyyah, (PT Raja Grafindi Persada:Jakarta), h. 58 


\section{Kesepakatan}

Dalam jual beli ada kesepakatan ijab dan qabul pada barang dan kerelaan berupa barang dan harga barang. ${ }^{22}$ Dalam jual beli Account Clash of Clans Calon pembeli menghubungi penjual yang bernegosiasi dengan penjual, setelah bernegosiasi dan sepakat dengan penjual, pembeli akan mentransfer sesuai dengan kesepakatan.

Dasar hukumnya terdapat dalam Surat Annisa' ayat 29:
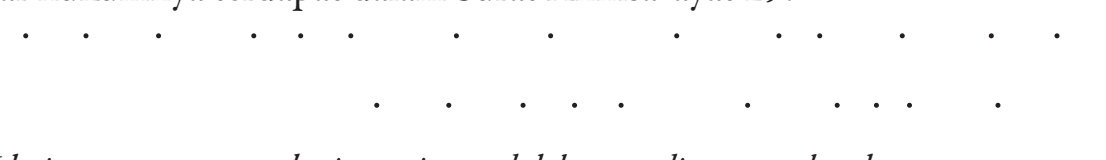

«Wahai orang-orangyang beriman, janganlah kamu salingmemakan harta sesamamu dengan jalan yang batil, kecuali dengan jalan perniagaan yang berlaku dengan suka sama suka di antara kamu. Dan janganlah kamu membunub dirimu; sesungguhnya Allah maha penyayang kepadamu”.

Untuk jual beli Account Clash of Clans tersebut sudah terdapat pihak-pihak yang berakad, yaitu penjual dan pembeli Account Clash of Clans. Objek dari jual beli tersebut kesepakatan antara penjual dan pembeli.

Berdasarkan hasil penelitian yang dilakukan dengan cara wawancara kepada admin grub "jual beli Account Clash of Clans " pembeli, penjual, dan juga gammer, mekanisme penyerahan Account Clash of Clans adalah sebagai berikut:

a. Penjual memposting Account yang akan dijual belikan dengan keterangan yang jelas mengenai level, harga dan kekurangan dari Account tersebut, beserta kontak person yang bisa dihubungi.

b. Calon pembeli menghubungi penjual yang bernegosiasi dengan penjual, setelah bernegosiasi dan sepakat dengan penjual, pembeli akan mentransfer sesuai dengan kesepakatan

c. Account baru bisa diberikan setelah pembeli memberikan bukti sudah melakukan transfer dengan memotret bukti transferan tersebut.

Dari segi kemanfaatan barang atau benda tersebut harus dapat dimanfaatkan dan bermanfaat bagi manusia. Oleh sebab itu, bangkai, khamr, darah, tidak sah menjadi objek jual beli, karena pandangan syara’ benda-benda seperti itu tidak bermanfaat bagi muslim.

Dalam uraian diatas secara rukun dan syarat dalam jual beli sesuai dengan hukum Islam. Akan tetapi jual beli account Clash of Clans barangnya tidak dapat dimanfaatkan bagi masyarakat luas meliankan hanya bermanfaat di kalangan gamer dan jika melihat dari dampak yang diakibatkan oleh jual beli Account Clash of Clans adalah tidak sesuai dengan asas akad yang yang berbunyi "akad 22 Sayyid Sabiq, Fiqh Sunnah (Alih Bahasa Oleh Kamaluddin A. Marzuki), Jilid 12,

(Bandung: Alma'arif,1988), h. 50. 
dilaksanakan dalam rangka menegakkan kemaslahatan, tidak mengandung unsur jebakan dan perbuatan buruk lainnya". ${ }^{23}$ Asas tersebut terdapat pada Kompilasi Hukum Ekonomi Syariah buku II Pasal 2 hurufj yang terdapat pada bab II.

\section{Analisis pandangan Ulama MUI Kota Malang dalam Transaksi Jual Beli Account Clash Of Clans (COC)}

Pada dasarnya game online itu masuk dalam lingkup dunia maya. Sedangkan dalam fiqh jual beli harus masuk dalam dunia nyata yang mana salah salah satu syaratnya yaitu barangnya harus ada dan dapat diserahterimakan, yang mana pada jual beli berlaku khiar, ijab qabul, semua itu harus dilaksanakan karena menghindari unsur-unsur penipuan, kemudharatan, pemalsuan dalam jual beli yang mana jual beli tersebut disyaratkan untuk kemaslahatan dan menghindari dari kemudharatan.

Syarat sahnya jual beli terdiri dari objek perjanjian salah satunya adalah dapat dimanfaatkan, Barang yang diperjualbelikan harus mempunyai manfaat, sehingga pihak yang membelinya tidak merasa dirugikan. Pengertian manfaat ini, tentu saja bersifat relatif. Karena pada dasarnya setiap barang mempunyai manfaat, sehingga untuk mengukur kriteria kemanfaatan ini hendaknya memakai kriteria agama. Pemanfaatan barang jangan sampai bertentangan dengan agama, peraturan perundang-undangan, kesusilaan, maupun ketertiban umum yang ada dalam kehidupan masyarakat. Selain itu juga disyaratkan Bahwa barang yang menjadi objek perjanjian jual beli harus benar-benar milik penjual secara sah adalah batal. Walau demikian pembeli yang beriktikad baik tetap mendapatkan perlindungan hukum dan tidak boleh dirugikan oleh adanya perjanjian yang batal ini.

Dalam konteks yang khusus ini memenuhi hal-hal yang mengarah pada ketidak syar'ian unsur-unsur jual beli dalam islam, yang mana akadnya sepihak. Aspek yang bertentangan dengan filosofis disyaratkan jual beli. Pada hadits Abdullab bin Abdil Malik, beliau berkata, "kami suatu saat berjalan bersama ayah kami diatas tandunya. Lalu dia berkata pada kami, 'bertasbihlah sampai dipohon itu. Lalu kami pun bertakbir. (HR.Az Zuhud II Ahmad bin Hambal, 3/321). Maksud dari hadits kita tidak boleh menyia-yiakan waktu begitu saja. Permainan Clash of Clans juga termasuk dalam konteks menyia-yiakan waktu, yang mana seharusnya waktu itu digunakan untuk melakukan kegiatan-kegiatan yang positif akan tetapi dalam hal ini waktunya terbuang sia-sia yang hanya digunakan begitu saja untuk bermain game padahal masih banyak kegiatan positif lainnya yang bisa dilakukan.

Permainan Clash Of Clans adalah permainan yang masuk pada kategori

23 Kompilasi Hukum Ekonomi Syariah, Buku II Pasal 21 huruf j, 
lahnaun atau lahwun, maksud dari kata labwun yaitu suatu perbuatan yang bertolak belakang dengan kegiatan masyarakat sekitar sehingga meninggal kewajibankewajiban atau kegiatan lainnya dengan menghabiskan waktu untuk bermain Clash OfClans. ${ }^{24}$ Sifat game banyak yang relatif dan kurang banyak manfaatnya, dan juga menyia-yiakan waktu dan mengandung (ada) aspek-aspek penipuan. ${ }^{25}$ Selain itu permainan Clash OfClans juga bisa berakibat akan meninggalkan sholat, belajar, makan, tidur, dll. Dan digantikan dengan bermain Clash OfClans.

Jual beli clash of clans ini merupakan suatu jual beli yang tidak jelas kemaslahatannya dan lebih banyak kemudharatannya. Jual beli account clash of clans secara akad tidak sah sedangkan secara normatif tidak sah dan juga tidak bermanfaat, pada intinya jual beli ini termasuk jual beli yang dilarang. ${ }^{26} \mathrm{Jual}$ beli Account Clash of Clans ini masuk dalam kategori unsur gharar dan juga tidak memenuhi unsurunsurnya dalam jual beli. Akan tetapi jumhur ulama tidak membedakan jual beli yang fasid dengan jual beli yang batil. Menurut mereka jual beli itu terbagi menjadi dua, yaitu jual beli yang shahih dan jual beli yang batil. Apabila syarat dan rukun jual beli terpenuhi, maka jual beli sah. Sebaliknya, apabila salah satu rukun dan syarat jual beli itu tidak terpenuhi, maka jual beli itu batil. ${ }^{27}$ Transaksi jual beli Account Clash of Clans tidak sah. Selain itu dalam Clash of Clans pada ada simbol setan-setan pada game Clash of Clans (COC) yang tidak disepakati dalam konteks islam contohnya pada level tinggi ( $\mathrm{TH} 9$ ) ada bangunan menyerupai ka'bah yang merupakan misi penyerangan game untuk menghancurkan bangunan tersebut. Jika dicermati secara perlahan hal ini menunjukkan akan penghancuran secara halus terhadap Islam yang diselundupkan dalam game. ${ }^{28}$

Setelah dianalisis dari subbab diatas maka secara umum dalam jual beli Account Clash of Clans ini akad tidak sah karena tidak sesuai dengan asas akad jual beli yakni akad dilaksanakan dalam rangka menegakkan kemaslahatan, dan dari segi kemanfaatan jual beli Account Clash of Clans hanya bisa dirasakan di kalangan gammer. Menurut ulama MUI Kota Malang jual beli Account Clash of Clans transaksi jualbeli Account Clash of Clans tidak sah.

\section{Simpulan}

Berdasarkan pembahasan, dapat diambil kesimpulan tentang jual beli account clash of clans dalam pandangan ulama MUI Kota Malang, yang pertama

24 Wawancara KH Chamzawi. 5 Agustus 2016. Malang

25 Wawancara KH Murtadho Amin. 9 Agustus 2016. Malang

26 Wawancara KH. Murtadho Amin. 9 Agustus 2016. Malang

27 Nasrun Haroen, Fiqih Muamalah, ( Jakarta: Gaya Media Pratama, 2000) h. 125-126

28 Wawancara KH Murtadho Amin. 9 Agustus 2016.Malang 
dalam jual beli Account Clash of Clans ini dimulai dari mempromosikan account ke media sosial, para pihak sudah mengetahui tentang spesifikasi, cara transaksi mulai dari penawaran sampai dari penyerahan account Clash of Clans. Tentunya dengan kesepakatan yang telah disepakati oleh kedua belah pihak. Yang kedua praktek jual beli Account Clash of Clans secara akad tidak sah karena tidak sesuai dengan asas akad jual beli yakni akad dilaksanakan dalam rangka menegakkan kemaslahatan. Menurut ulama MUI Kota Malang jual beli Account Clash of Clans transaksi jual beli Account Clash of Clans tidak sah.

\section{Daftar Pustaka}

Al-Jaziri, Abdurrahman, FighEmpatMadzhab 6, Jakarta: Darul Ulum Press, 2001.

Ghazali, Abdul Rahman dkk, FiqhMuamalah, Jakarta: Prenada Media Group, 2010

Hasan, Muhammad Ali.Berbagai Macam Transaksi Dalam Islam; Fiqh Muamalah, Jakarta: Raja GrafindoPersada, Cet. 1, 2003.

Haroen, Nasrun, Fiqih Muamalah, Jakarta: Gaya Media Pratama, 2000.

Musbikin, Imam, qawaid al-fiqhiyyah, Jakarta: PT Raja Grafindi Persada2001

Sabiq, Sayyid, Fiqih Sunnah jilid 4, Jakarta: Pena Pundi Aksara, 2006

Sabiq, Sayyid. Fiqh Sunnah (Alih Bahasa Oleh Kamaluddin A. Marzuki), Jilid 12, Bandung: Almảarif, 1988.

Syafe'I, Rachmat, Fiqh Mualalah, Bandung, Pusaka Setia, 2001.

Perundang-Undangan

Kompilasi Hukum Ekonomi Syariah, Buku II Pasal 20 ayat 19

Kompilasi Hukum Ekonomi Syariah, Buku II Pasal 21 hurufj

Website

http://id.wikipedia.org/wiki/Clash_of_Clans

https://jalantikus.com

http://www.fadli.xyz/2015/05/hukum-jual-beli-barang-game-online.html 